\title{
FOODS AND FOOD GROUPS ASSOCIATED WITH COLORECTAL CANCER: A CASE-CONTROL STUDY
}

\author{
LAURA IOANA GAVRILAȘ ${ }^{1}$, CORINA IONESCU ${ }^{2}$, OVIDIU BĂLĂCESCU ${ }^{3}$, CORNELIA \\ REVNIC $^{4}$, DANIELA CIOBÂRCA ${ }^{1}$, LORENA FILIP $^{1}$, ANAMARIA BOBOIA ${ }^{5 *}$, DOINA MIERE ${ }^{1}$ \\ ${ }^{I}$ Department of Bromatology, Hygiene, Nutrition, “Iuliu Haţieganu” University of Medicine and Pharmacy, 23 Marinescu \\ Street, Cluj-Napoca, Romania \\ ${ }^{2}$ Department of Pharmaceutical Biochemistry and Clinical Laboratory, "Iuliu Haţieganu” University of Medicine and \\ Pharmacy, 6 Louis Pasteur Street, Cluj-Napoca, Romania \\ ${ }^{3}$ Department of Functional Genomics, Proteomics and Experimental Pathology, The Oncology Institute "Prof. Dr. Ion \\ Chiricuţă", 34-36 Republicii Street, Cluj-Napoca, Romania \\ ${ }^{4}$ Department of Mathematics-Informatics, "Iuliu Haţieganu” University of Medicine and Pharmacy, 6 Louis Pasteur Street \\ 400349, Cluj-Napoca, Romania \\ ${ }^{5}$ Department of Pharmaceutical Management, Marketing and Legislation, "Iuliu Hatieganu" University of Medicine and \\ Pharmacy, 8 Victor Babeş Street, 400012, Cluj-Napoca, Romania
}

*corresponding author: aboboia@umfcluj.ro

\begin{abstract}
Dietary habits act as important determinants of cancer risk and are especially associated with colorectal cancer (CRC), one of the most important diet-related types of cancer. In this regard, the main goal of the present study was to investigate the risk and protective dietary factors related with CRC in Romanian population. A case-control study was conducted from August 2015 until January 2017. Data was collected from cancer-free controls $(n=151)$ and CRC cases $(n=151)$ using a food frequency questionnaire. The questionnaire was completed during a face-to-face interview led by a trained dietitian. The results showed that intake of poultry, fish, and fibre-rich foods are inversely associated with CRC risk. Furthermore, dietary habits linked with a Western diet such as high intake of processed meat, sugar-sweetened beverages, white bread and dessert $(\mathrm{p}=0.001)$ were more frequent in the CRC group.
\end{abstract}

\section{Rezumat}

Obiceiurile alimentare acționează ca factori determinanți ai riscului de cancer și sunt îndeosebi asociate riscului de cancer colorectal (CCR), unul dintre cele mai importante tipuri de cancer corelate cu regimul alimentar. Obiectivul principal al acestui studiu a fost evaluarea dietei ca factor de risc sau de protecție în cancerul colorectal prin intermediul unui studiu efectuat, efectuat în perioada august 2015 - ianuarie 2017. Au fost incluşi 302 participanţi distribuiţi în grupul experimental $(\mathrm{n}=151)$ și în grupul control $(\mathrm{n}=151)$, iar informațiile legate de dietă au fost obținute prin intermediul unui chestionar, în timpul unui interviu realizat de către un dietetician. Rezultatele au arătat că un consum frecvent de pui, pește şi alimente bogate în fibre sunt invers asociate riscului de cancer, în timp ce obiceiurile alimentare caracteristice dietei de tip vestic, precum consumul de carne procesată, dulciuri și sucuri îndulcite au fost mai frecvente în grupul pacienților cu CCR.

Keywords: colorectal cancer, diet, risk factors, protective factors

\section{Introduction}

Colorectal carcinoma accounts for $10 \%$ of all cancers worldwide. It is the third most common type of cancer among men, being exceeded only by breast cancer in women [1]. In Romania, both incidence and mortality are increasing, although in most developed countries rates have decreased over the past two decades due to early detection programs and improved treatment protocols $[12,13,26]$.

Over $75 \%$ of cases of colorectal cancer (CRC) are sporadic and follow the adenoma-carcinoma pathway [39]. Environmental and lifestyle factors, especially diet and nutrition habits, have a strong influence on the development and prevention of CRC $[4,16]$. The most relevant dietary risk factors associated with CRC risk include high intakes of red and processed meat [2], while following a healthy diet based on fruit, non-starchy vegetables, legumes, whole grains and fish has been shown to reduce the incidence of CRC and to play a key role for prevention [3, 4, 37]. Protective mechanisms are based on the action of bioactive dietary components which have antioxidant, anti-inflammatory and anti-tumorigenic properties and can modify gene expression through epigenetic mechanisms [15]. Also, extended exposure to risk factors leads to molecular changes in oncogenes and tumour suppressor genes that favour the occurrence of malignant phenotype [28]. 
FARMACIA, 2018, Vol. 66, 5

In Romania, available epidemiological data shows that prevalence of overweight and obesity in the adult population is $30-36 \%$ and $20-25 \%$ respectively, with a high frequency of unhealthy lifestyle habits [31]. Since both obesity and dietary factors are main risk factors for CRC, it is of main importance to explore the relationship between diet and $\mathrm{CRC}$ in our population. In this context, we designed a case-control study with the main objective to investigate pre-diagnostic lifestyle habits (physical activity, smoking, dietary habits) of CRC patients in a Romanian sample [5-8, 14]. Our analysis aimed to evaluate the frequency of consumption of different foods and food groups together with culinary techniques and explore the possible dietary risk or protective factors associated with CRC.

\section{Materials and Methods}

\section{Ethical consideration}

According to the Declaration of Helsinki, as a statement of ethical principles for medical research involving human subjects, the Treaty of Amsterdam, and Directive 2010/63/EU of the European Parliament and of the Council of 22 September 2010 on the protection of animals used for scientific purposes, in force, there has been obtained the approval of the Ethical Commission of "Iuliu Haţieganu" University of Medicine and Pharmacy Cluj-Napoca, Romania, for the present study. Study design and population

There has been designed a case-control study which was conducted in Romania from August 2015 until January 2017. The patients were recruited from "Medisprof" Oncology Hospital from Cluj-Napoca, Romania, and the inclusion criteria for the CRC group were Romanian nationality and a recent diagnostic of cancer in any region of the colon and/or rectum. The control group was recruited from generally healthy adults, following a regular diet and included participants without neoplastic diagnosis or other major chronic diseases in the present or in the past. Study groups were matched by age within a 5-year category. Each participant signed an informed consent to participate in the study.

Data collection

A questionnaire was administered individually using face-to-face interviews conducted by a trained dietitian and the questions aimed to assess usual food intake over the previous year. In the absence of a validated national tool for evaluation of food intake, the applied questionnaire was established by members of the research team using validated models from other countries $[8,11]$. Participants were asked to report frequency of consumption for a given food and/or food group based on weekly intake. The questions included in this analysis evaluated the intake of dairy products, meat, fat, sweets and grains, together with some questions addressing culinary practices.

Statistical analysis

The statistical analyses were provided based on SPSS software (Statistic Package for Social Sciences) version 20. Differences between groups regarding frequency of consumption of selected foods and food groups were determined by a Mann Whitney U test [30]. The odds ratio (OR) and the corresponding $95 \%$ confidence interval $(\mathrm{CI})$ were measured by logistic regression analysis to determine possible risk or protective factors correlated to CRC in selected dietary factors. A p value less that 0.05 was considered to indicate statistical significance.

\section{Results and Discussion}

The baseline characteristics of participants in the study group are presented in Table I.

Baseline characteristics of the participants included in the analysis

\begin{tabular}{|c|c|c|c|c|c|c|}
\hline Parameter & \multicolumn{3}{|c|}{ Patients } & \multicolumn{3}{|c|}{ Control } \\
\hline Sex (Female/Male) & $\mathbf{F}(\mathrm{n}=59)$ & $\mathbf{M}(\mathrm{n}=92)$ & $\mathbf{F}+\mathbf{M}(\mathrm{n}=151)$ & $\mathbf{F}(\mathrm{n}=61)$ & $\mathbf{M}(\mathrm{n}=90)$ & $\mathbf{F}+\mathbf{M}(\mathrm{n}=151)$ \\
\hline Age (years) & $54.8 \pm 11.3$ & $59.3 \pm 11.6$ & $57.1 \pm 11.4$ & $56 \pm 10.1$ & $60 \pm 11.4$ & $58.4 \pm 11.4$ \\
\hline $\begin{array}{l}\text { BMI }\left(\mathbf{k g} / \mathbf{m}^{\mathbf{2}}\right) \\
<24.9 \\
25.0-29.9 \\
>30\end{array}$ & $\begin{array}{c}28(18.5 \%) \\
16(10.5 \%) \\
15(9.9 \%)\end{array}$ & $\begin{array}{c}59(39.3 \%) \\
23(15.2 \%) \\
10(6.6 \%)\end{array}$ & $\begin{array}{l}81(53.6 \%) \\
45(29.8 \%) \\
25(16.6 \%)\end{array}$ & $\begin{array}{c}44(72.1 \%) \\
17(27.9 \%) \\
0(0 \%)\end{array}$ & $\begin{array}{c}41(45.5 \%) \\
45(50 \%) \\
4(4.4 \%)\end{array}$ & $\begin{array}{c}85(56.3 \%) \\
62(41 \%) \\
4(2.7 \%)\end{array}$ \\
\hline $\begin{array}{l}\text { Education } \\
\leq \text { Secondary school } \\
\text { Completed high school } \\
\text { or equivalent } \\
\text { Bachelor degree or higher }\end{array}$ & $\begin{array}{c}9(15.2 \%) \\
43(72.8 \%) \\
7(11.8 \%)\end{array}$ & $\begin{array}{c}10(10.8 \%) \\
75(81.5 \%) \\
7(7.6 \%)\end{array}$ & $\begin{array}{c}19(12.6 \%) \\
118(78.1 \%) \\
14(9.3 \%)\end{array}$ & $\begin{array}{c}4(6.5 \%) \\
26(42.6 \%) \\
31(50.8 \%)\end{array}$ & $\begin{array}{c}5(5.5 \%) \\
40(44.5 \%) \\
45(50 \%)\end{array}$ & $\begin{array}{c}9(6 \%) \\
99(65.6 \%) \\
76(50.4 \%)\end{array}$ \\
\hline Living in urban area no. (\%) & $48(81.3 \%)$ & $73(79.3 \%)$ & $121(80.1 \%)$ & $51(83.6 \%)$ & $77(85.5 \%)$ & $128(84.8 \%)$ \\
\hline
\end{tabular}

Different mechanisms have been proposed to explain the complex relationship between diet and the risk of CRC, as well as for protective properties of some healthy foods or dietary patterns. These mechanisms are based on the concept that high-risk diets rich in red and processed meat, refined grains, sugar or fat generate great levels of colon carcinogens [2, 22], while protective diets containing vegetables, fruits, dietary fibres or $\omega$-3 fatty acids, are powerful sources of vitamins, minerals and bioactive components with 
FARMACIA, 2018, Vol. 66, 5

chemopreventive potential [15]. In this study, we evaluated the frequency of consumption of different food groups (dairy, meat, fats, sweets and grains).
Furthermore, the calculated odds ratios for selected foods in the study sample are presented in Table II.

Table II

Dietary risk or protective factors associated with CRC

\begin{tabular}{lccc}
\hline \multicolumn{1}{c}{ Independent variable } & OR (odd ratio) & $\mathbf{9 5 \%}$ CI (confidence interval) & p value \\
\hline Processed meat (servings/week) (3 - 5) & 6.94 & $2.60-18.47$ & $<0.001$ \\
\hline White bread (servings/week) ( $>$ 5) & 16.06 & $8.66-29.78$ & $<0.001$ \\
\hline Sweets and dessert (servings/week) (3 - 5) & 1.59 & $0.97-2.59$ & 0.063 \\
\hline Fish (servings/week) (3 - 5) & 0.09 & $0.02-0.3$ & $<0.001$ \\
\hline Poultry and turkey (servings/ week) (3 - 5) & 0.37 & $0.23-0.60$ & $<0.001$ \\
\hline Whole grains (servings/week) (3 - 5) & 0.058 & $0.02-0.12$ & $<0.001$ \\
\hline Whole bread (servings/week) (3 - 5) & 0.33 & $0.20-0.55$ & $<0.001$ \\
\hline
\end{tabular}

\section{Meat and fish}

The intakes of meat and fish for both patients and control groups are presented in Table III. Interestingly, in our study, no differences were observed between groups regarding red meat intake $(\mathrm{p}>0.05)$ or hightemperature meat cooking (data not shown). However, intakes of processed meat differ significantly between groups $(\mathrm{p}<0.001)$ and increase the risk of CRC (Table II). Furthermore, we observed that intakes of lean poultry meat and fish were significantly higher in

the control group compared with CRC group (Table III). Likewise, regular intake of 3 - 5 servings/week of lean poultry meat is inversely associated with CRC risk $(\mathrm{OR}=0.37,95 \% \mathrm{CI}=0.23-0.60, \mathrm{p}<0.001)$ along with the same weekly frequency of fish intake which also was shown to decrease the risk of CRC $(\mathrm{OR}=0.09,95 \% \mathrm{CI}=0.02-0.3, \mathrm{p}<0.001)$. In line with our findings, the inverse association with elevated intakes of fish and lean meat on CRC has been reported previously [33, 34].

Table III

Comparison between meat and fat intake between participants

\begin{tabular}{lccc}
\hline \multicolumn{1}{c}{ Parameter } & Control & Patients & p value \\
\hline Red meat (servings/week) & & & 0.123 \\
$<1$ & $49(32.5 \%)$ & $25(16.6 \%)$ & \\
$1-2$ & $49(32.5 \%)$ & $74(49 \%)$ & \\
$3-5$ & $47(31.1 \%)$ & $47(31.1)$ & \\
$>5$ & $6(4 \%)$ & $5(3.3 \%)$ & \\
\hline Processed meat (servings/week) & & & $<0.001$ \\
$<1$ & $99(65.6 \%)$ & $58(38.4 \%)$ & \\
$1-2$ & $45(29.8 \%)$ & $59(39.1 \%)$ & \\
$3-5$ & $5(3.3 \%)$ & $29(19.2 \%)$ & \\
$>5$ & $2(1.3 \%)$ & $5(3.3 \%)$ & \\
\hline Poultry and turkey (servings/week) & & & \\
$<1$ & $32(21.2 \%)$ & $27(17.9 \%)$ & \\
$1-2$ & $32(21.2 \%)$ & $75(49.7 \%)$ & \\
$3-5$ & $81(53.6 \%)$ & $46(30.5 \%)$ & \\
$>5$ & $6(4 \%)$ & $3(2 \%)$ & \\
\hline Fish (servings/week) & & & \\
$<1$ & $26(17.2 \%)$ & $60(39.7 \%)$ & \\
$1-2$ & $95(62.9 \%)$ & $85(56.3 \%)$ & \\
$3-5$ & $27(17.9 \%)$ & $3(2 \%)$ & \\
$>5$ & $3(2 \%)$ & $3(2 \%)$ & \\
\hline
\end{tabular}

Colorectal cancer and red meat consumption have a long history together and the most recent report from World Health Organization (WHO) classified processed meat as carcinogenic to humans (Group 1) based on sufficient evidence in humans that the consumption of processed meat causes colorectal cancer. WHO experts concluded that each 50 grams portion of processed meat eaten daily increases the risk of colorectal cancer by $18 \%$ [38]. Epidemiological studies have highlighted over time that high intakes of red and processed meat contribute to colon carcinogenesis $[2,27]$. One proposed mechanism was attributed to haem iron contained in red meat. Haem iron can generate $\mathrm{N}$-nitroso compounds which promote colorectal tumorigenesis by increased cell proliferation and DNA damage [2, 27]. Also, cooking meat at high temperature leads to formation of potent mutagens such as polycyclic amines and polycyclic aromatic hydrocarbons, both of which have carcinogenic potential [35]. Curiously, in our study we did not find statistically significant differences in relation with cooking techniques between the two groups (data not shown). 
It has been hypothesized that negative effects derived from a high red meat diet can be countered by consuming healthy foods rich in anticarcinogenic compounds, through epigenetic mechanisms. Results from a recent in vivo study demonstrated that a high red meat diet supplemented with butylated starch, which is known as a colon protective dietary agent, modulated miRNA expression in the colon mucosa [21]. A recent case-control study, reported also no significant differences between cases of CRC and controls regarding intakes of red meat [3]. However, in

our sample, even if we found no differences between groups in terms of red meat intake, participants in the control group had higher intakes of foods and food groups known as protective for CRC [15].

Dairy products

The intake of dairy products is further presented in Table IV. The results indicate that intakes of full-fat milk, skimmed milk, sour cream and fermented cheese are significantly different between groups $(p<0.05)$, while similar intakes of yogurt and melted cheese were observed among cancer cases as compared with controls.

Table IV

Intakes of dairy products among participants

\begin{tabular}{|c|c|c|c|}
\hline Parameter & Control & Patients & p value \\
\hline Full fat milk (servings/week) & & & 0.002 \\
\hline$<1$ & $108(71.5 \%)$ & $83(54.9 \%)$ & \\
\hline $1-2$ & $34(22.5 \%)$ & $48(31.8 \%)$ & \\
\hline $3-5$ & $7(4.6 \%)$ & $18(11.9 \%)$ & \\
\hline$>5$ & $2(1.3 \%)$ & $2(1.4 \%)$ & \\
\hline Skimmed milk (servings/week) & & & $<0.001$ \\
\hline$<1$ & $21(13.9 \%)$ & $95(62.9 \%)$ & \\
\hline $1-2$ & $21(13.9 \%)$ & $52(34.4 \%)$ & \\
\hline $3-5$ & $94(62.3 \%)$ & $1(0.7 \%)$ & \\
\hline$>5$ & $15(9.9 \%)$ & $3(2 \%)$ & \\
\hline Sour cream (servings/week) & & & $<0.001$ \\
\hline$<1$ & $99(65.6 \%)$ & $63(41.7 \%)$ & \\
\hline $1-2$ & $33(21.9 \%)$ & $65(43 \%)$ & \\
\hline $3-5$ & $15(9.9 \%)$ & $21(13.9 \%)$ & \\
\hline$>5$ & $4(2.6 \%)$ & $2(1.3 \%)$ & \\
\hline Yogurt (servings/week) & & & 0.781 \\
\hline$<1$ & $6(4 \%)$ & $5(3.3 \%)$ & \\
\hline $1-2$ & $22(14.6 \%)$ & $43(28.5 \%)$ & \\
\hline $3-5$ & $120(79.5 \%)$ & $80(53 \%)$ & \\
\hline$>5$ & $3(2 \%)$ & $23(15.2 \%)$ & \\
\hline Melted cheese (servings/week) & & & 0.576 \\
\hline$<1$ & $96(63.6 \%)$ & $93(61.6 \%)$ & \\
\hline $1-2$ & $44(29.1 \%)$ & $49(32.5 \%)$ & \\
\hline $3-5$ & $9(6 \%)$ & $8(5.3 \%)$ & \\
\hline$>5$ & $2(1.3 \%)$ & $1(0.7 \%)$ & \\
\hline Fermented cheese (servings/week) & & & 0.027 \\
\hline$<1$ & $43(28.5 \%)$ & $9(6 \%)$ & \\
\hline $1-2$ & $50(33.1 \%)$ & $84(55.6 \%)$ & \\
\hline $3-5$ & $55(36.4 \%)$ & $56(37.1 \%)$ & \\
\hline$>5$ & $3(2 \%)$ & $2(1.3 \%)$ & \\
\hline
\end{tabular}

The relationship between dairy consumption and $\mathrm{CRC}$ has been explored in other epidemiological or case-control studies and the evidence indicates a protective effect $[9,23,24,29]$. In line with our results, a Saudi case-control study reported different intake patterns regarding dairy intake [3]. In the EPIC (European Prospective Investigation into Cancer and Nutrition) cohort study, higher intakes of dairy have been associated with reduced risk of CRC [24], as well as in Swedish and Finnish cohorts [23, 29]. Furthermore, results from a recent meta-analysis estimated a relative risk of $0.91(95 \% \mathrm{CI}=0.85-0.94)$, indicating a negative association between milk intake and the risk of CRC [36].
The biological mechanism associated with the protective effect may be due to high calcium and vitamin D contents which were shown to enhance apoptosis and cell differentiation $[10,36]$. In human colon cancer cells, calcitriol can block Wnt signalling in multiple ways and interferes with inflammatory pathways related to cancer progression such as NF-k $\beta$ (nuclear factor kappa-light-chain-enhancer of activated $\mathrm{B}$ cells) and COX-2 (cyclooxygenase-2) [18]. Furthermore, vitamin D modulates miRNA expression and DNA methylation and thereby inhibits proliferation of colon cancer cells through epigenetic regulation [15]. Another proposed mechanism refers to the ability of calcium and vitamin $\mathrm{D}$ to reduce the exposure of the colonic epithelium to the harmful effect of free fatty acids by 
FARMACIA, 2018, Vol. 66, 5

forming a complex with the bile salts and free fatty acids [36]. Moreover, the lipid fractions of dairy products including butyric acid and conjugated linoleic acid may have chemopreventive properties [25]. In vitro studies showed that both agents protect against tumorigenesis by decreasing inflammation and inhibiting cell proliferation $[4,25,33]$.

Grains and sweets

From our data, intake of white bread, sweets and desserts along with sugar-sweetened beverages was significantly higher in the CRC group $(\mathrm{p}<0.05)$, while intakes of refined grains (white pasta, white flour, etc.)

and pastry products were similar between groups (Table V). Results showed that $22.5 \%$ of participants in the CRC group consumed 3 - 5 servings of white bread on a weekly basis, while only $17.9 \%$ of the participants in the control group consumed white bread with this frequency. Also, we found an increased risk of CRC with 3 - 5 servings/week of white bread intake (Table II). On the contrary, the intake of 3 - 5 servings/week of whole bread and 3 - 5 servings/week of whole grains reduces the risk of $\mathrm{CRC}, \mathrm{OR}=0.33$ $(95 \% \mathrm{CI}=0.20-0.55, \mathrm{p}<0.001)$ and $\mathrm{OR}=0.05$ $(95 \% \mathrm{CI}=0.02-0.12, \mathrm{p}<0.001)$ respectively.

Table V

Intakes of sweets and refined starches

\begin{tabular}{lccc}
\hline \multicolumn{1}{c}{ Parameter } & Control & Patients & p value \\
\hline White bread (servings/ week) & & & $<0.001$ \\
$<1$ & $41(27.2 \%)$ & $3(2 \%)$ & \\
$1-2$ & $67(44.4 \%)$ & $15(9.9 \%)$ & \\
$3-5$ & $27(17.9 \%)$ & $34(22.5 \%)$ & \\
$>5$ & $16(10.6 \%)$ & $99(65.6 \%)$ & 0.106 \\
\hline Refined starches (servings/ week) & & & \\
$<1$ & $35(23.2 \%)$ & $8(5.3 \%)$ & \\
$1-2$ & $76(50.3 \%)$ & $108(71.5 \%)$ & \\
$3-5$ & $35(23.2 \%)$ & $34(22.5 \%)$ & \\
$>5$ & $5(3.3 \%)$ & $1(0.7 \%)$ & \\
\hline Pastry products (servings/ week) & & & \\
$<1$ & $70(46.4 \%)$ & $63(41.7 \%)$ & \\
$1-2$ & $55(36.4 \%)$ & $53(35.1 \%)$ & \\
$3-5$ & $25(16.6 \%)$ & $32(21.2 \%)$ & \\
$>5$ & $1(0.7 \%)$ & $3(2 \%)$ & \\
\hline Sweets and dessert (servings/ week) & & & \\
$<1$ & $40(26.5 \%)$ & $15(9.9 \%)$ & \\
$1-2$ & $47(31.1 \%)$ & $47(31.1 \%)$ & \\
$3-5$ & $40(26.5 \%)$ & $55(36.4 \%)$ & \\
$>5$ & $24(15.9 \%)$ & $34(22.5 \%)$ & \\
\hline Sweetened beverages (servings/ week) & & & \\
$<1$ & $94(62.3 \%)$ & $104(68.9 \%)$ & \\
$1-2$ & $17(11.3 \%)$ & $34(22.5 \%)$ & \\
$3-5$ & $31(20.5 \%)$ & $11(7.3 \%)$ & \\
$>5$ & $9(6 \%)$ & $2(1.3 \%)$ & \\
\hline & &
\end{tabular}

A previous case-control study conducted in France reported similar results for white bread, with the French baguette being highly popular in that population [34], while another study from Saudi Arabia found no differences concerning type of bread usually eaten [3]. Although a recent meta-analysis found no association between sugar-sweetened beverages or refined grains and CRC risk [33], these dietary habits are representative for a Western dietary pattern which was previous associated with CRC [22].

High intake of refined grains, white bread, sweets and sugar-sweetened beverages might contribute to CRC risk due to their influence on insulin resistance, which is a risk factor for colorectal cancer [19, 32]. Refined carbohydrates and simple sugars are rapidly digested and induce high glucose concentrations in the blood followed by elevated insulin response. Afterwards, an increased circulating level of insulin facilitates the overexpression of IGF-1 (insulin-like growth factor 1) and thus may support colon carcinogenesis [20]. Strengths and limitations of the present study should be considered. First, the study group is relatively small. In addition, the retrospective nature of casecontrol studies has inherent limitations. Additionally, the instrument used for data collection did not support estimation of energy intake, which is an important risk factor for CRC, although we did adjust for BMI (Body Mass Index). Furthermore, participants have been included in the CRC group only by confirming the diagnostic of colon and/or rectum cancer, without inquiring about the specific site or histological classification, which may represent another limitation of the study. Finally, it can be observed that participants in the CRC group were less educated and this may lead to overestimation of healthy foods or underestimation of risk factors due to increased awareness and knowledge in the more educated participants from 
control group. The study was designed with special care regarding the dietary interviews which were conducted face-to-face by a trained dietitian. However, it is utterly important that nutrition specialists and epidemiologists from our country join forces and develop a validated national tool for assessing food intake in our population, to better evaluate the link between diet and disease.

\section{Conclusions}

In conclusion, we identified some foods such as white bread, processed meat and sweets consumed more frequently by patients in the CRC group which were significantly associated with the risk of colorectal cancer, while intake of fish, poultry and foods rich in dietary fibres were shown to have protective effects in the study sample. Interestingly, red meat which was frequently associated with CRC in other populations had similar intake patterns in cases and controls.

\section{Acknowledgement}

The authors wish to thank the dietitian in the hospital for advising patients to participate and for the support regarding data collection.

\section{References}

1. American Cancer Society, Global Cancer Facts \& Figures, $3^{\text {rd }}$ Edition, 2015; www.cancer.org/content/ dam/cancer-org/research/cancer-facts-and-statistics/ global-cancer-facts-and-figures/global-cancer-factsand-figures-3rd-edition.pdf.

2. Aykan NF, Red meat and colorectal cancer. Onco Rev., 2015; 9(1): 288-332.

3. Azzeh FS, Alshammari EM, Alazzeh AY, Jazar AS, Dabbour IR, El-Taani HA, Obeidat AA, Kattan FA, Tashtoush SH, Healthy dietary patterns decrease the risk of colorectal cancer in the Mecca Region, Saudi Arabia: A case-control study. BMC Public Health, 2017; 17(1): 1-8.

4. Baena R, Salinas P, Diet and colorectal cancer. Maturitas, 2015; 80(3): 258-264.

5. Boboia A, Feher LA, Cuc S, Moldovan M, Comparative study between the sales of antiulcer drugs $\mathrm{H} 2$ antagonists and Proton Pump Inhibitors. Farmacia, 2017; 65(4): 635-642.

6. Boboia A, Oros GC, Polinicencu C, Mirel S, Researches concerning the profitability of the community pharmacy within the context of world economic and financial crisis. Farmacia, 2014; 62(5): 1025-1036.

7. Boboia A, Polinicencu C, Application of the Pareto analysis regarding the research on the value of preparations in community pharmacies from ClujNapoca, Romania. Farmacia, 2012; 60(4): 578-585.

8. Buscemi S, Rosafio G, Vasto S, Massenti FA, Grosso G, Galvano F, Rini N, Barile AM, Maniaci V, Cosentino L, Validation of a food frequency questionnaire for use in Italian adults living in Sicily. Int J Food Sci Nutr., 2015; 66(4): 426-438.

9. Cho E, Smith-Warner SA, Spiegelman DW, Beeson L, van den Brandt PA, Colditz GA, Folsom AR, Fraser GA, Freudenheim JL, Giovannucci E, Goldbohm AR, Graham S, Miller AB, Pietinen P, Potter JD, Rohan TE, Terry P, Toniolo P, Virtanen MJ, Willett WC, Wolk A, Wu K, Yaun SS, Jacquotte A, Hunter DJ, Dairy foods, calcium, and colorectal cancer: a pooled analysis of 10 cohort studies. $J$ Natl Cancer Inst., 2004; 96(13): 1015-1022.

10. Davoodi H, Esmaeili S, Mortazavian AM, Effects of Milk and Milk Products Consumption on Cancer: A Review. Compr Rev Food Sci Food Saf., 2013; 12(3): 249-264.

11. Deschamps V, de Lauzon-Guillain B, Lafay L, Borys JM, Charles MA, Romon M, Reproducibility and relative validity of a food-frequency questionnaire among French adults and adolescents. Eur J Clin Nutr., 2009; 63(2): 282-291.

12. Ferlay J, Shin HR, Bray F, Forman D, Mathers C, Parkin D, Donald M, Estimates of worldwide burden of cancer in 2008: GLOBOCAN 2008. Int J Cancer, 2010; 127(12): 2893-2917.

13. Ferlay J, Soerjomataram I, Dikshit R, Eser S, Mathers C, Rebelo M, Parkin DM, Forman DD, Bray F, Cancer incidence and mortality worldwide: sources, methods and major patterns in GLOBOCAN 2012. Int $J$ Cancer, 2014; 136(5): 359-386.

14. Gavrilas L, Ionescu C, Balacescu O, Muresan D, Revnic C, Filip L, Miere D, Intake of plant based foods and colorectal cancer. A case-control study in Romania. Bulletin of the University of Agricultural Sciences and Veterinary Medicine Cluj-Napoca. Food Sci Tech., 2018; (in press).

15. Gavrilas L, Ionescu C, Tudoran O, Lisencu C, Balacescu O, Miere D, The Role of Bioactive Dietary Components in Modulating miRNA Expression in Colorectal Cancer. Nutrients, 2016; 8(10): 590-609.

16. Gonzalez CA, Riboli E, Diet and cancer prevention: Contributions from the European Prospective Investigation into Cancer and Nutrition (EPIC) study. Eur J Cancer, 2010; 46(14): 2555-2562.

17. van Harten-Gerritsen AS, Balvers MGJ, Witkamp RF, Kampman E, van Duijnhoven FJB, Vitamin D, inflammation, and colorectal cancer progression: a review of mechanistic studies and future directions for epidemiological studies. Cancer Epid Biomarkers Prev., 2015; 24(12): 1820-1828.

18. Hegheș SC, Gavrilaș LI, Pralea IE, Filip L, CozmaPetruț A, Iuga CA, Suharoschi R, Miere D, Evaluation of energy and nutrient intake from food of lactating mothers in a Romanian sample. Farmacia, 2018; 66(2): 243-247.

19. Hillon P, Guiu B, Vincent J, Petit JM, Obesity, type 2 diabetes and risk of digestive cancer. Gastroentérologie clinique et biologique, 2010; 34(10): 529-533.

20. Howarth NC, Murphy SP, Wilkens LR, Henderson $\mathrm{BE}$, Kolonel LN, The association of glycemic load and carbohydrate intake with colorectal cancer risk in the Multiethnic Cohort Study. Am J Clin Nutr., 2008; 88(4): 1074-1082.

21. Humphreys KJ, Conlon MA, Young GP, Topping DL, Hu Y, Winter JM, Bird AR, Cobiac L, Kennedy NA, 
Michael MZ, Le Leu RK, Dietary manipulation of oncogenic microRNA expression in human rectal mucosa: a randomized trial. Cancer Prev Res., 2015; 7(8): 786-795.

22. Kasdagly M, Radhakrishnan S, Reddivari L, Vanamala $\mathrm{J}$, Colon carcinogenesis: Influence of western dietinduced obesity and targeting stem cells using dietary bioactive compounds. Nutrition, 2014; 30(11-12): 1242-1256.

23. Larsson SC, Bergkvist L, Rutegård J, Giovannucci E, Wolk A, Calcium and dairy food intakes are inversely associated with colorectal cancer risk in the Cohort of Swedish Men. Am J Clin Nutr., 2006; 83(3): 667-673.

24. Murphy N, Norat T, Ferrari P, Jenab M, Bueno-deMesquita B, Skeie G, Olsen A, Tjønneland A, Dahm CC, Overvad K, Consumption of Dairy Products and Colorectal Cancer in the European Prospective Investigation into Cancer and Nutrition (EPIC). PLOS ONE, 2013; 8(9): e72715.

25. Norat T, Riboli E, Dairy products and colorectal cancer. A review of possible mechanisms and epidemiological evidence. Eur J Clin Nutr., 2003; 57(1); 1-17.

26. Oncology Institute "Prof. Dr. Ion Chiricuţă" ClujNapoca, National Cancer Registry north-west, Cancer report in north-western region of Romania, 2014; www.iocn.ro.

27. Oostindjer M, Alexander J, Amdam GV, Andersen G, Bryan NS, Chen D, Corpet DE, De Smet S, Dragsted LO, Haug A, Karlsson AH, Kleter G, de Kok TM, Kulseng B, Milkowski AL, Martin RJ, Pajari AM, Paulsen JE, Pickova J, Rudi K, Sødring M, Weed DL, Egelandsdal B, The role of red and processed meat in colorectal cancer development: a perspective. Meat Sci., 2014; 97(4): 583-596.

28. Pappou EP, Ahuja N, The role of oncogenes in gastrointestinal cancer. Gastrointest Cancer Res., 2010; Suppl 1: S2-S15.

29. Pietinen P, Malila N, Virtanen M, Hartman TJ, Tangrea JA, Albanes D, Virtamo J, Diet and risk of colorectal cancer in a cohort of Finnish men. Cancer Causes Control, 1999; 10(5): 387-396.
30. Revnic C, Câmpean R, Boboia A, Analysis of market data regarding the medicines used in treatment of dyslipidaemia. Farmacia, 2015; 63(4): 613-618.

31. Roman G, Bala C, Creteanu G, Graur M, Morosanu M, Amorin P, Pircalaboiu L, Radulian G, Timar R, Achimas Cadariu A, Obesity and health-related lifestyle factors in the general population in Romania: a cross sectional study. Acta Endocrinologica, 2015; 11(1): 64-71.

32. Rondini EA, Harvey AE, Steibel JP, Hursting SD, Fenton JI, Energy balance modulates colon tumor growth: Interactive roles of insulin and estrogen. Mol Carcinog., 2011; 50(5): 370-382.

33. Schwingshackl L, Schwedhelm C, Hoffmann G, Knüppel S, Laure Preterre A, Iqbal K, Bechthold A, De Henauw S, Michels N, Devleesschauwer B, Boeing $\mathrm{H}$, Schlesinger $\mathrm{S}$, Food groups and risk of colorectal cancer. Int $J$ Cancer, 2018; 142(9): 1748-1758.

34. Senesse P, Boutron-Ruault MC, Faivre J, Chatelain N, Belghiti C, Méance S, Foods as risk factors for colorectal adenomas: a case-control study in Burgundy (France). Nutr Cancer, 2002; 44(1): 7-15.

35. Shabbir MA, Raza A, Anjum FM, Khan MR, Suleria HAR, Effect of thermal treatment on meat proteins with special reference to heterocyclic aromatic amines (HAAs). Crit Rev Food Sci Nutr., 2015; 55(1): 82-93.

36. Song M, Garrett WS, Chan AT, Nutrients, foods, and colorectal cancer prevention. Gastroenterology, 2015; 148(6): e16: 1244-1260.

37. Wang Q, Hao J, Guan Q, Yuan W, The Mediterranean diet and gastrointestinal cancers risk. Recent Patents on Food, Nutrition and Agriculture, 2014; 6(1): 23-26.

38. World Health Organization/International Agency for Research on Cancer (WHO/IARC), Monographs evaluate consumption of red meat and processed meat, 2015; www.iarc.fr.

39. Yamagishi H, Kuroda H, Imai Y, Hiraishi H, Molecular pathogenesis of sporadic colorectal cancers. Chin J Cancer, 2016; 35(4): 1-8. 